\title{
Actual Behaviors of Newly Observed Phraseological Units Comprising Two Prepositions
}

\author{
Ai Inoue ${ }^{1}$ \\ ${ }^{1}$ Associate Professor, Department of Foreign Languages, National Defense Academy of Japan, Japan. \\ Correspondence: Ai Inoue, Department of Foreign Languages, National Defense Academy of Japan, 1-10-20 \\ Hashirimizu, Yokosuka City, Kanagawa Prefecture, 239-8686, Japan. E-mail: aiinoue@nda.ac.jp
}

Received: May 12, 2014

doi: 10.5539/ijel.v4n4p74
Accepted: June 13, $2014 \quad$ Online Published: July 29, 2014

URL: http://dx.doi.org/10.5539/ijel.v4n4p74

\begin{abstract}
This paper describes, from a phraseological perspective, phrases created by combining two prepositions into a complex preposition (CP), defined as a word group that functions as a single preposition; for example, into, within, and upon. In particular, this work focuses on the newly observed CPs on against and in to and proposes that be on against and be in to are newly observed phraseological units in contemporary English, which have not yet been described in previous research or English dictionaries. A recent trend in English is to combine two prepositions into new CPs such as in at, and in for. In particular, two adverbial particles in and on co-occur with various prepositions and help establish new CPs. For example, MED ${ }^{2}$ (Macmillan English Dictionary, 2nd edition) lists new CPs such as in at, in for, in on, on about, and on at. Data obtained from corpora of present-day English show that on against and in to mainly co-occur with be verbs, and be on against and be in to are also observed. However, an extensive literature review shows that previous research and English dictionaries do not address this trend. This research describes their polysemy in different contexts, their functions, formations, and stress patterns.
\end{abstract}

Keywords: be on against, be in to, complex preposition, contemporary English, corpora, phraseology, phraseological units

\section{Introduction}

Present-day English changes by the hour. Mair and Leech (2006) and Leech et al. (2009) summarized English grammatical changes observed in English over the last few decades by showing data obtained from corpora (Note 1). Research on the changes in present-day English, including Mair and Leech (2006) and Leech et al. (2009), mainly focus on describing English lexical changes and grammaticalization. However, little attention has been paid to showing the actual behavior of newly emerged phrases (generally defined as repeatedly used word-combinations consisting of at least two words). English dictionaries recently published in Europe and the United States attempt to keep current with newly observed phrases, but their descriptions cannot entirely document their actual behavior.

Phraseology, the study of phrases, is based on the idea that phrases play an essential role in the efficiency of language use. When we read a newspaper, we can easily find a large number of phrases consisting of already known and familiar phrases. However, we do not entirely understand their full meanings and such phrases are ubiquitous in language and constitute a significant resource for communication. Further, although such phrases help English as Foreign Language (EFL) learners sound as fluent as native speakers of English, such phrasal expressions can cause difficulties for EFL learners, who need to understand them to gain native-like proficiency in English. Hence, the study focuses on the distribution and behavior of phrases, which have been overlooked so far and not yet been correctly understood.

This study focuses on the following two points. First, it documents the actual behaviors of newly observed phrases such as on against and in to from corpus data, with the assumption that the meanings of phrases are closely related to their syntactic patterns. In addition, it describes these newly observed phrases as having their own grammatical function as complex prepositions and co-occurring with the be, as in be on against and be in to. In other words, the phrases comprise two function words that behave as a content word because sentences including these phrases do not make sense without them. This phenomenon is the opposite of grammaticalization - that is, they represent a form of degrammaticalization. Second, the study shows how the 
phrases functioning as complex prepositions are formed, referring to the general rules of word formations.

\section{Phraseology}

\subsection{Definitions and Goals}

\subsubsection{What is Phraseology?}

As a general word, phraseology is defined as "(A) choice of arrangement of words and phrases; style of expression; the particular form of this which characterizes a language, author, work, etc." (Shorter Oxford Dictionary, 6th edition). Therefore, phraseology can be used as unique English phraseology (compared with other languages), Hemingway's phraseology (i.e., the characteristics of expressions and stylistics) and legal phraseology (i.e., words, terms, and phrases only used in legal discourse).

In linguistic research, the subfield of phraseology addresses collocations (Note 2), idioms (Note 3), multi-word expressions (Note 4), and formulae (Note 5). However, practically, the coverage of phraseology is much wider and included the syntactic patterns such as the possible complements of verbs, predicative adjectives, and nouns. Consequently, phraseology is a linguistic research field dealing with individual linguistic phenomena or irregularities.

In phraseology, the phrases under discussion have been given varied labels: phraseological unit, phraseme, recurrent-word combinations, or fixed expressions and idioms. The study adopts the most generic term, phraseological units (PUs).

\subsection{Relevance of Phraseology}

Increased attention to phraseology has been largely due to the advancement of corpus linguistics, the growing interest in lexicography, and the phraseological application for language education, among other factors. The syntactic rules and lexicons assumed in existing linguistic theories are suited for explaining the roles a large number of PUs play in contexts where they are applied for language acquisition and use. Cowie (1998) and Howarth (1999) show that there is significant difference in the use of collocations between academic papers written in English by native and non-native English speakers. In other words, the naturalness of a target language is revealed in the use of PUs. It is possible to infinitely generate sentences by using the syntactic rules and lexicons explained in linguistic theories, but there is no guarantee that the sentences generated in this manner will sound as fluent English, even if they are grammatically correct and semantically congruent. Phraseology investigates what phrases sound consistent with native speech, and can inform language teaching aimed at native-like speech.

\subsection{Function of PUs}

The significance of PUs originally came from the necessity for effective foreign language education, as expressed in the following:

(1) ... communicative competence is not a matter of knowing rules for the composition of sentences... It is much more a matter of knowing a stock of partially pre-assembled patterns, formulaic frameworks, and a kit of rules, so to speak, and being able to apply the rules to make whatever adjustments are necessary according to contextual demands. Communicative competence in this view is essentially a matter of adaptation, and rules are not generative but regulative and subservient. (Widdowson, 1989, p. 135, also quoted in Willis, 2003, p. 142)

This idea completely differs from linguistic theory, which focuses on syntax. (1) states that patterns or PUs such as multi-word expressions or formulae lie at the heart of language. Grammatical rules merely play a coordinating role subordinate to PUs. Hence, it is clear from this that the knowledge necessary for communication is about a large number of PUs and patterns, and not about grammatical rules.

\section{Methodology}

\subsection{Theoretical Assumptions}

The present study is a descriptive investigation that examines linguistic phenomena concretely and does not rely on any major linguistic theory such as those of generative grammar. The basic thesis on which this research is based is the theory of semantic syntax, which is based on the assumption that the part of the meaning of a word is closely related to the syntactic characteristics of the word. 


\subsection{Definitions}

As described in 2.1, phraseology is an inclusive term for the study of phrases.

As Cowie (1998) states, "in phraseology, as in other fields within linguistics, it is not uncommon for individual scholars to apply different terms to the same category (or the same term to different categories). I have, therefore, thought it essential - while not suppressing individual differences - to provide a general framework, in which the terms used by any one individual can be understood in relation to those used by others." As mentioned in 2.1, this study adopts the most widespread term in phraseological research, phraseological units (PUs), defined as repeatedly used word-strings consisting of at least two words.

\subsection{Data}

Data used in this study comes from BNC, Word Banks Online, the Corpus of Contemporary American English (COCA), and the Larry King Live Corpus (Note 6) A corpus study is optimal for this investigation for the following three reasons, as noted by Sampson (2001).

First, it is objective because a corpus is simply a collection of actual spoken and written text. In addition, a corpus study permits easy access to data for language research requiring spontaneously generated data.

Next, it is a basic requirement of research for a third party to verify the research results. Corpora make it possible for a third party to verify the research results. In other words, human intuitions, which allow no access to any person besides the researcher, would not make objective data available for validation by a third party.

The final advantage of using a corpus is that it allows researchers whose native language is not the language under investigation (in the present case, English) to study that language on an equal footing with native-speaking researchers. Corpus studies simply make it easier for non-native speaks to have access to quality data (Inoue, 2007).

\subsection{Stress Patterns of Phraseological Units}

Inoue (2009) investigated and analyzed the stress patterns of various PUs, and then proposed four tentative rules for PU stress patterns, shown in (2).

(2) a. Stress patterns of phrases cannot be predicted simply by whether a word is a function or content word

b. Stress is placed on the word with which a speaker wants to convey the most important meaning

c. Set phrases have stable stress patterns, as do words

d. Set phrase does not necessarily consist of one tone group and each word consisting of set phrases has each tone (Inoue, 2009, pp. 133)

This study investigates whether the four rules adapt to the stress patterns of PUs (be on against and be in to) by analyzing them using the phonetic analysis software, Praat (Note 7).

\subsection{Word-formation Processes}

There has been a good deal of discussion in the literature on word formation (Allen, 1978; Bauer, 1983; Bybee, 1985; Ito \& Sugioka, 2002; Lieber, 1983; Pinker, 1994; Plag, 2003; Siegel, 1974; Nishikawa, 2013) among others. (3) summarizes the general processes of word formation:
(3) a. compounding
e.g., sleep walk, highway
b. derivation
e.g., unkind
c. borrowing
e.g. nintendo
d. conversion
e.g., Xerox (n.) - xerox (v).
e. acronym
e.g., CALL, CIA, FBI
f. backformation$$
\text { e.g., begger } \rightarrow \text { beg }
$$
g. shortening
e.g., mathematics $\rightarrow$ math, gasoline $\rightarrow$ gas
h. blending
e.g., breakfast + lunch $\rightarrow$ brunch
i. lexicalization of phrases e.g., catch-me-if-you-can, passer(s)-by
j. metaanalysis

$$
\text { e.g., hamburger } \rightarrow \text { ham }+ \text { burger (rather hamburg }+ \text {-er) }
$$


k. root creation e.g., bow-wow, hic, zzz, beep, sniff, snore

It is natural to assume that new words are coined by combining familiar and well-known words. This process is very similar to kennings in Old English, which produced new words by combining previously existing words. Processes (3a), (3b), (3e), and (3f) are highly productive. It is noteworthy that the PUs discussed in this study differs from new words coined through the processes in (3), in that the PUs are composed solely of free morphemes such as on and against. However, this study shows how the process in (3) can help explain the formation of newly observed PUs.

\section{Complex Prepositions}

Prepositions are morphologically classified into the three types: (i) polysemous simple prepositions such as at, in, and of; (ii) complex prepositions comprising two or more prepositions (e.g., into, within, in front of), some of which are polysemous, but others monosemous; (iii) monosemous group prepositions formed by a preposition and another category (e.g., according to, in accordance with, with regard to, etc.).

This study applied a CP to phrases comprising "a preposition + (an element) + a preposition" and defined CPs as PUs repeatedly used in different contexts. In reference to the classification of prepositions in Yasui (1983), this study adopts group prepositions for CPs used in Quirk et al. (1985), Akimoto (1999, 2002, 2005), Quirk and Mulholland (1968), Hoffman (2001, 2004, 2005), and Tottie and Hoffman (2001).

$\mathrm{MED}^{2}$ lists new word combinations used with be such as be in at, be in for, be in on under the entry for in, be on about, and be on at under the entry for on. In addition, Oxford Advanced Learner's Dictionary, 8th edition $\left(\mathrm{OALD}^{8}\right)$ describes be in at, be in for, be in on, and be in with as word combinations. It is not difficult to find new word combinations besides those listed in English dictionaries in contemporary English corpora such as COCA; for example, in and of, in and out, on against, and in to. This study focuses on on against and in to.

A word combination must serve one of several functions to be considered a CP. These functions are listed in (4):

(4) a. place adverb

b. sentence adverb

c. intransitive verb complement

d. predicate adverbial (with linking verb)

e. transitive verb complement

f. nominal modifier

g. prepositional adverb

h. transitive verb complement adverbial

i. modification by adverbs (rare)

The CPs on against and in to only fulfill condition (4d). We can see from (3) that not all word combinations consisting of two prepositions fulfill the conditions shown in (4).

\section{The PU Be On Against}

This section examines how be on against functions in context and how it evolved.

\subsection{Functions of On and Against}

No attempt has been made to give a functional explanation of be on against. On, as discussed in this work, appears as the complement of be and functions as an adverb. It is used to mean that something is happening. In case words like actor/actress, TV program, or movie appear as a subject and follow on, on is used to show that the actor/actress, TV program, or movie is being broadcast. Please look at the following examples of on quoted from dictionaries.
a. Eastenders is on TV tonight.
b. What time is Star Trek on?
c. She'll be on soon.
d. You should go to Chicago while the festival is on.

$\left(\mathrm{MED}^{2}\right)$

$\left(\mathrm{LDCE}^{5}\right)$

(Youth)

\section{(Longman)}

A preposition against is commonly understood to mean "in opposition to somebody or something," which means that it retains its lexical meaning. Also, there is no significant different in the definition of against in previous studies. 


\subsection{Meanings of be on against}

The function of be on against is described in the section. The following are a few examples of its use (italicized by the author).

(6) KING: One hour?

MCGRAW: It's going to be an hour.

KING: You said 3:00, 4:00 in the afternoon. Are you going to be on against Oprah?

MCGRAW: Oh, absolutely not. My mama didn’t raise a fool.

(Larry King Live, Feb., 2002)

(7) KING: -would they have stayed with you?

DON HEWITT: -we've been on what, 29 years?

MIKE WALLACE: Twenty-eight.

DON HEWITT: I would have taken 29 weeks. Well, it will be 29 .

KING: You were on against Marcus Welby, right?

DON HEWITT: Marcus Welby, M.D. Great doctor. ～(Larry King Live, May, 1996)

(8) KING: She, of course, is starting her fourth season this Monday on-she's with Paramount domestic television. She's in 217 markets. And now her rival, replacing Mayor Ed Koch as the host of "The People's Court," is Judge Jerry Sheindlin, and that show is produced by Warner Brothers. And in many markets, they will be on against each other. Why, Jerry?

(Larry King Live, Sep., 1999)

(9) KING: Bill Moyers - simply one of the best. Sports for Sale tomorrow night on PBS, a three-hour special including your phone calls. We'll be back tomorrow night with a full hour with H. Ross Perot-We'll be on against each other. Americans have a great choice tomorrow! Wolf Blitzer is on The Larry King Radio Show in one hour. Bernard Shaw and Susan Rook are next. Good night.

(Larry King Live, Mar., 1991)

(10) KING: .... And of course, he hosts the "Dr. Phil Show," syndicated. You would have to check newspapers in your area for time and station. One thing though, if you see Oprah, he won't be on against her. It's a Harpo. It's involved in the productions and they ain't going to allow that. (COCA, spoken, 2001)

On the basis of the above examples, be on against is used most often to mean "compete." In that case, be on against appears in the syntactic pattern of "subject + be on against." Its prototypical syntactic pattern is "subject + be on against." Two other syntactic patterns also occur for be on against: "subject (somebody, a TV or radio program) + be on against + somebody/ a TV or radio program" and "subject (somebody or races) + be on against + each other." The first one is used to mean that somebody or a TV/radio program is competing with another person or TV/radio program broadcast simultaneously on another station. Examples (6), (7), and (10) exemplify the first pattern. The second is used to express the idea people or races are competing with each other. Examples (8) and (9) exemplify this usage.

Let us examine some of the preceding examples. In (6), King and McGraw are discussing Oprah Winfrey, who hosts a popular talk show in the U.S. Be on against is used to ask McGraw whether his talk show will compete with his show broadcast simultaneously on another station. Be on against in (7) is used to show that the program co-hosted by Hewitt and Wallace for 28 years has been competing with Marcus Welby, which aired at the same time. In (8), the second syntactic pattern (subject + be on against + each other) is used. The pattern means that the two programs under discussion competed against each other as if in a series of market competitions.

The above examples of be on against lead us to believe that be on against is used to show that a person, TV/ radio programs simultaneously compete with someone else or another TV/radio program. This is the major difference between go against and be on against.

\subsection{Analysis of be on against}

As is commonly assumed, be on against syntactically consists of [be on] [against], as in [The war is on] [against poverty], which means that the war to eliminate poverty continues. However, [be on against] is reanalyzed as a lexical unit by its repeated use, coming to hold the idiomatic meaning compete. For example, [the war is on] [against poverty] becomes [the war [is on against] poverty], which means that the war continues as a fight against poverty. By moderate advances, any word implying compete can appear as the subject of a sentence, so be on against develops the meaning that one program or person competes with another that is counterprogrammed. The formation of be on against suits for metaanalysis and lexicalization of phrases already mentioned in (2). On against co-occurs with a noun (phrase), so it has a function as a complex preposition within 
grammatical category and a function word in sentences. However, on against semantically behaves like a verb and is essential in sentences. This is a very interesting example in contemporary English, in which a PU consists of functions words acting as a content word.

\subsection{Distribution of Verbs with on against}

Verbs besides be can be used with on against: go, work, carry, focus, hold, hang, move, come, and keep. From a cursory examination of these verbs, the following fact emerges: All verbs co-occurring with on are established as phrasal verbs (e.g., go on, work on, carry on, focus on, hold on, hang on, move on, come on, and keep on). To cite a couple of examples, carry on against syntactically consists of [carry on] [against] and work on against is formed of [work on] [against]. The syntactic structure pattern holds true for other phrasal verbs. In other words, expressions such as work on against, hold on against, and focus on against result from phrasal verbs such as work on and come on appearing alongside against. Hence, the lexical meanings of each phrasal verb survive.

On the other hand, be is the most appropriate verb for on against to show its meaning (i.e., compete) because other verbs such as go, come, carry, focus, and hold are not semantically bleached, as is be. In other words, be is the most semantically bleached verb (i.e., unmarked) and it does not impede the meaning of on against.

\subsection{Stress Patterns of be on against}

I asked seven native speakers of English (four Americans, a Canadian, a speaker of British English, and an Australian) to read the following passages in (11) to confirm whether the tentative stress rules of PUs in (2) are valid in the case of be on against.

(11) a. KING: .... And of course, he hosts the "Dr. Phil Show," syndicated. You would have to check newspapers in your area for time and station. One thing though, if you see Oprah, he won't be on against her.

b. KING: One hour?

MCGRAW: It's going to be an hour.

KING: You said 3:00, 4:00 in the afternoon. Are you going to be on against Oprah?

MCGRAW: Oh, absolutely not. My mama didn't raise a fool.

c. DON HEWITT: We've been on what, 29 years?

MIKE WALLACE: Twenty-eight.

DON HEWITT: I would have taken 29 weeks. Well, it will be 29.

KING: You were on against Marcus Welby, right?

DON HEWITT: Marcus Welby, M.D... Great doctor.

d. KING: She, of course, is starting her fourth season this Monday on - she's with Paramount domestic television. She's in 217 markets. And now her rival, replacing Mayor Ed Koch as the host of "The People's Court" is Judge Jerry Sheindlin, and that show is produced by Warner Brothers. And in many markets, they will be on against each other. Why, Jerry?

e. KING: Was it a hit right away?

VAN DYKE: No. We went in the toilet the first year.

KING: You are kidding!

VAN DYKE: We were on against "Perry Como," which was a very, very popular show. And, of course, my name didn't mean any -nobody had ever heard of me.

f. KING: .... They have lit it up in blue and white tonight, the colors of the New York Yankees, who are participating in their 35th World Series. As you know, they're on against us. But, this program is repeated at midnight, Eastern time, 9:00 Pacific.

g. KING:.... We'll be back tomorrow night with a full hour with H. Ross Perot-We'll be on against each other. Americans have a great choice tomorrow! Wolf Blitzer is on The Larry King Radio Show in one hour. Bernard Shaw and Susan Rook are next. Good night. 
Table 1. Stress patterns of be on against

\begin{tabular}{ccccc}
\hline & be ón against & be on ágainst & be ón ágainst & sum \\
\hline (11a) & 6 & 1 & 0 & 7 \\
$(11 \mathrm{~b})$ & 7 & 0 & 0 & 7 \\
$(11 \mathrm{c})$ & 6 & 1 & 0 & 7 \\
$(11 \mathrm{~d})$ & 6 & 1 & 0 & 7 \\
$(11 \mathrm{e})$ & 6 & 0 & 1 & 7 \\
$(11 \mathrm{f})$ & 7 & 0 & 0 & 7 \\
$(11 \mathrm{~g})$ & 7 & 0 & 1 & 7 \\
\hline
\end{tabular}

The following facts emerge from Table 1. First, in be on against, on is generally stressed. In other words, rule (2c) holds for be on against. Primary stress falls on on because be is pronounced as a weak form, meaning rule (2b) is valid. Finally, (2d) is true for be on against because some informants put stress on all components of be on against.

\section{6. $P U$ be in to}

This section examines be in to, a newly observed PU in contemporary English, not described in previous research nor in English dictionaries. We demonstrate that in to behaves as a CP.

Consider the following examples of be in to appearing in contemporary English (italicized by the author).

(12) WHITFIELD So, is it feasible, in your opinion, to think that a shuttle could be launched by this fall?

CABBAGE: I think it's feasible. But I think it may be in to 2005 before the shuttle actually does fly. There are a lot of people within NASA who think that it's going to take that long, not only to make the organizational changes, get them underway, but also hardware changes they'll have to make as well.

(COCA, spoken, 2004)

(13) BILL HEMMER, CNN CORRESPONDENT: Miles, good morning to you again from Tallahassee. Again, that deadline coming up quickly, tomorrow five o'clock when any amended votes have to be in to the Secretary of State's office here in Tallahassee.

(COCA, spoken, 2000)

(14) Mr. RODRIGUEZ: .... Police can't do what mothers and fathers and schools and churches and other things should be doing. In many ways the police are dealing with the back end of the problem. The kids already are raging; already has a gun in his hand; already is in to the drug trade.

(COCA, spoken, 1993)

(15) GREENBERG: I know a little bit about him. I know that he grew up in the north suburbs, ended up in Plainfield, which is way in the far south suburbs. He's an avid hunter, loves to hunt. I don't know if that adds anything to the case or not. And he knows a lot about the criminal law aspects, because he was in to some computer criminalistics kind of specialty work that he was trying to develop.

(COCA, spoken, 2007)

(16) "Listen, Phil. I know you can listen even if you can't talk. Do you know the whereabouts of Rose Hilaire? She hasn't been in to Belmodes, and is not answering her phone...."

(BNC, written, 1990)

What do all of these examples of be in to mean? Are they used in the same manner semantically? The three tentative findings are as follows: (i) Be in to tends to have been used mainly in spoken English, and British and American English. Even the Database of Analysed Texts of English (DANTE), which contains a large number of phrases, does not contain be in to; (ii) be in to is observed in any tense and aspect; and (iii) be in to is frequently used with a noun (phrase), implying a location.

\subsection{Difference Between be into and be in to}

Quirk et al. (1985) and Ishibashi (ed.) (1966) note that onto can be spelled as on to in British English and that there is no semantic and functional difference between onto and on to. Similar to onto, there is concern that in to is the same as into. This section clarifies the issue. Consider the examples of be into. 
(17) a. I was not into ambition, manipulation, or the politics of getting on.

(DANTE)

b. At home, everyone is into health-food and diet drinks.

c. Q: Are you into pilates or yoga?

d. Suddenly, she's into yoga and things like that.

$\left(\mathrm{MED}^{2}\right)$

These examples illustrate that be into is used to state what activity or subject someone is interested in, and that be into is followed by an abstract or a common noun implying activity or subject. In contrast, be in to in (13) to (17) co-occurs with a proper noun (e.g., a place) or a common noun. Consequently, be into and be in to appear in distinct environments with different uses.

\subsection{Behavior of be in to in Natural Speech}

This section describes the actual behavior of be in to in various contexts.

6.2.1 Functions of in and to

According to $\mathrm{MED}^{2}$, in and to have the following functions as demonstrated in (18) and (19), respectively.

(18) a. used for showing where someone or something is

b. into something

c. arriving somewhere

d. used for showing when something happens

e. used for talking about numbers and amounts

f. used for stating areas of activity

g. used for describing a particular state, situation, or relationship

h. wearing something

i. used for stating what changes

j. used for talking about the way something is done

k. used for describing ways of writing, drawing, or painting

1. included as part of a group

m. used for describing how things are arranged

n. used for referring to colours

o. used for referring to the weather

p. used for mentioning the book, film etc where someone or something appears

q. used for showing in what way something is true

r. written or drawn to complete something

s. doing something with a particular feeling

t. given, sent, or received

u. used for stating what contains a particular substance

v. available at a shop

w. used for stating who is BATTING in CRICKET

$\mathrm{x}$. used for stating who or what has particular qualities

y. elected

z. fashionable

$\alpha$. when the sea is high

$\beta$. breaking inwards

$\left(\mathrm{MED}^{2}\right)$

(19) a. used as part of an infinitive

b. going somewhere

c. when you tell, give, or show someone something 
d. facing or pointing towards someone/something

e. used for saying where someone/something is

f. when someone is affected by something

g. in a particular relationship with someone/something

(i) used for explaining a relationship between people or thing

(ii) used for stating which person or organization someone does a particular job

h. when something is connected or fastened

i. when something changes or develops

j. as far as a limit

k. until

1. before the hour

m. used for stating someone's opinion

n. causing a particular reaction

o. used for showing how numbers are related

p. used for giving the score in a game

q. closed or almost closed.

r. used for showing a possible range

s. needed for something

t. while there is a sound.

u. touching something

$\left(\mathrm{MED}^{2}\right)$

6.2.2 Meaning and Function of be in to

Examples (20), (21), (22), (23), and (24) are the same as Examples (12), (13), (14), (15), and (16). Example (26) is quoted from the corpora.

(20) WHITFIELD So, is it feasible, in your opinion, to think that a shuttle could be launched by this fall?

CABBAGE: I think it's feasible. But I think it may be in to 2005 before the shuttle actually does fly. There are a lot of people within NASA who think that it's going to take that long, not only to make the organizational changes, get them underway, but also hardware changes they'll have to make as well. (COCA, spoken, 2004)

(21) BILL HEMMER, CNN CORRESPONDENT: Miles, good morning to you again from Tallahassee. Again, that deadline coming up quickly, tomorrow five o'clock when any amended votes have to be in to the Secretary of State's office here in Tallahassee.

(COCA, spoken, 2000)

(22) Mr. RODRIGUEZ: .... Police can't do what mothers and fathers and schools and churches and other things should be doing. In many ways the police are dealing with the back end of the problem. The kids already are raging; already has a gun in his hand; already is in to the drug trade. And we want them to resolve the issues....

(COCA, spoken, 1993)

(23) GREENBERG: I know a little bit about him. I know that he grew up in the north suburbs, ended up in Plainfield, which is way in the far south suburbs. He's an avid hunter, loves to hunt. I don't know if that adds anything to the case or not. And he knows a lot about the criminal law aspects, because he was in to some computer criminalistics kind of specialty work that he was trying to develop.... (COCA, spoken, 2007)

(24) "Listen, Phil. I know you can listen even if you can't talk. Do you know the whereabouts of Rose Hilaire? She hasn't been in to Belmodes, and is not answering her phone....."(BNC, written, 1990)

(25) ELLIE JOSTAD, NANCY GRACE PRODUCER: .... They'd spend some time together in the afternoon. And then Dad would go back to the house, which he was trying to make more habitable for the kids. So, apparently, he was unaware that the kids hadn't been in to school all last week until on Saturday, he got a letter from the school saying they'd been absent. 
As noted in Section 6.1, be in to tends to be used mainly in spoken British and American English, and is frequently used with a noun (phrase), implying a location. This is seen in examples from (20) to (25).

Be in to appears in all tenses and aspects; however, semantic differences distinguish past and present tense be in to and perfective has/have been in to. Consider Examples (24) and (25). When be in to is used in the perfect aspect, it tends to appear in negative sentences and means that someone has arrived at a place and stayed there. In other words, has/have been in to is a monosemous expression. The reason why has/have been in to has not evolved into a polysemous expression is the survival of the original meaning of the verb be (present) and the influence of similar expressions have been in/to.

However, be in to is a polysemous PU and the meanings of be in to differ according to the nouns be in to takes as its complement, as seen in Table 2:

Table 2. Meaning and complements of be in to and has/have been in to

\begin{tabular}{lll}
\hline Examples & Meanings of be in to & Complements \\
\hline$(20)$ & reach & be in to + a number \\
$(21)$ & arrive at and stay & be in to + a place \\
$(22)$ & get involved in & be in to + an occupation \\
$(23)$ & get involved in & be in to + an occupation \\
$(24)$ & have arrived at and stayed & have been in to + a place \\
$(25)$ & have arrived at and stayed & have been in to + a place \\
\hline
\end{tabular}

Furthermore, the following finding can be drawn from Table 2: The functions of to are decisive elements that give a specific meaning to be in to in each context. As Example (19) illustrates, to is a multifunctional preposition. Table 3 summarizes the function of to in Example (19) that greatly influences the meaning of be in to. Please note that Table 3 does not include the examples of has/have been in to.

Table 3. Functions of to that influences to decide the meaning of be in to in contexts

\begin{tabular}{llll}
\hline Examples & Meanings of be in to & Syntactic patterns & Functions \\
\hline$(20)$ & reach & be in to + a number & (19d) direction, arrival \\
$(21)$ & arrive at and stay & be in to + a place & (19b) destination \\
$(22)$ & get involved in & be in to + an occupation & $(19 \mathrm{~g})$ (ii) organization \\
$(23)$ & get involved in & be in to + an occupation & (19g) (ii) organization \\
\hline
\end{tabular}

Tables 4 and 5 confirm that be in to is a new PU because of its frequent use in contemporary English, that it is a polysemous $\mathrm{PU}$, that the function of to is critical to the complete meaning of be in to in each context, and that in to functions as a $\mathrm{CP}$ because it is followed by a noun or noun phrase.

\subsubsection{Stress assignment for be in to}

I asked seven informants (an English, two Americans, three Canadians, and an Australian) to read Example (26) to verify whether each hypothesis in Example (2) is supported. Table 4 reports the informants' responses:

(26) a. I think it is feasible. But I think it may be in to 2005 before the shuttle actually does fly. There are a lot of people within NASA who think that it is going to take that long, not only to make the organizational changes and get them underway but also hardware changes they will have to make as well.

b. Again, that deadline coming up quickly, tomorrow five o'clock when any amended votes have to be in to the Secretary of State's office here in Tallahassee.

c. Police cannot do what mothers and fathers and schools and churches and other things should be doing. In many ways the police are dealing with the back end of the problem. The kids already are raging; already has a gun in his hand; already is in to the drug trade. 
d. I know that he grew up in the north suburbs, ended up in Plainfield, which is way in the far south suburbs. He's an avid hunter, loves to hunt. I don't know if that adds anything to the case or not. And he knows a lot about the criminal law aspects, because he was in to some computer criminalistics kind of specialty work that he was trying to develop....

e. Do you know the whereabouts of Rose Hilaire? She has not been in to Belmodes, and is not answering her phone.

f. And then Dad would go back to the house, which he was trying to make more habitable for the kids. So, apparently, he was unaware that the kids had not been in to school all last week until on Saturday, he got a letter from the school saying they had been absent.

g. Are you a total woman now? And you think that is the best position to be in to counsel people like Nikki and Lisa and Angie and...

Table 4. Stress assignments of be in to and have been in to

\begin{tabular}{lllll}
\hline & be ín to & be in tó & be ín tó & sum \\
\hline$(26 a)$ & 0 & 7 & 0 & 7 \\
$(26 b)$ & 0 & 6 & 1 & 7 \\
$(26 c)$ & 0 & 7 & 0 & 7 \\
$(26 d)$ & 0 & 6 & 1 & 7 \\
$(26 \mathrm{e})$ & 2 & 3 & 2 & 7 \\
$(26 \mathrm{f})$ & 2 & 5 & 0 & 7 \\
$(26 \mathrm{~g})$ & 0 & 7 & 0 & 7 \\
\hline
\end{tabular}

The results in Table 6 demonstrate that $t o$ is the main determinant of the meaning of be in to because the primary stress is put on to. Thus, Hypotheses (2a) and (2c) are supported.

In Examples (26e) and (26f), the results concern the stress patterns of has/have been in to. Similar to be in to, the semantic focus of has/have been in to is on to because the stress is on to. However, stress assignment for has/have been in to changes in response to the position with the most semantic importance, that is, the constituent in or to. Hypothesis (2c) applies to this case.

In Rows (26b) and (26d) of Table 6, the primary stress of be in to is on both in and to; thus, Hypotheses (2b) and (2d) are supported.

Consequently, the four interim rules for the PU stress patterns stated in Hypotheses (2a)-(2d) are supported for be in to and has/have been in to.

6.2.4 Semantic Derivation and Origins of be in to

This section discusses the semantic derivation and evolution of be in to.

\subsubsection{Semantic Derivation}

Examples of be in to in contemporary English show that its core meaning is "to arrive at a place/destination," and that its typical syntactic patterns is [be in to + a place/destination]. Thus, the extended meanings of be in to such as reach, get involved in, and turn into have evolved, and as the outlying meanings develop, the lexical or literal meanings of in and to undergo semantic bleaching.

\subsubsection{Distribution of be in to}

The pattern [[a verb + in] [to] + a noun (phrase)] affects the distribution of be in to. Verbs used in the pattern retrieved from $\mathrm{BNC}$ are as follows:

(27) add, address, allow, book, boot, box, break, breath, bring, build, burst, call, come, carry, cave, connect, creep, cut, draft, drag, draw, drive, drop, extend, fall, fill, fit, fly, give, get, go, hand, head, hook, hurry, import, incorporate, indulge, input, invite, jump, lead, let, link, listen, lock, log, look, move, phone, plug, pop, pour, pull, put, race, reach, report, ring, roll, rope, run, rush, send, settle, step, swim, take, tax, tie, tuck, tune, turn, walk, work, write, zoom 
When the verbs in (27) appear in the pattern [[a verb + in] [to] + a noun (phrase)], such as [[break in] [to] + a noun (phrase)], in is an adverb and to is a preposition. In addition to the verbs listed in (27), various other verbs appear in the pattern [[a verb + in] [to] + a noun (phrase)], and the new pattern [[be in] [to] + a noun (phrase)] evolves through repeated use. The new pattern becomes [be in to + a noun (phrase)] by metaanalysis followed by lexicalization. With the newly established pattern [be in to + a noun (phrase)], in changes its function into a preposition, and in to works as a new CP. Be of [be in to + a noun (phrase)] is semantically bleached, so the various meanings of to in Example (20) generate polysemous be in to.

\section{Stress Pattern Rules and Formation of New PUs}

Only rules (2c) and (2d) hold for be on against and be in to. Rule (2a) does not hold because neither be on against nor be in to contain content words. As for rule (2b), both be on against and be in to are polysemous PUs; therefore, their meanings are not compositional. Thus, it is very difficult to decide which component is the most important in each PU. Both be on against and be in to were formed by metaanalysis followed by lexicalization.

\section{Conclusion}

Based on data obtained from corpora on contemporary English, this study described newly introduced PUs consisting of function words and has explained their meanings and functions as CPs. This study has also shown how the PUs be on against and be in to became established and how the stress patterns for PUs apply to be on against and be in to. Interestingly, the PUs discussed in the study function as content words in sentences despite being formed by function words.

\section{References}

Akimoto, M. (1999). The idiomatization and grammaticalization of complex prepositions. In S.-J. J. Hwang, \& A. R. Lommel (Eds.), The Twenty-second LACUS forum XXV (pp. 389-397).

Akimoto, M. (2002). Grammaticalization and idioms. Tokyo: Hitsuji Syobou.

Akimoto, M. (2005). About complex prepositions, Eigo Gohou Bunpou Kenkyuu Studies on English usage and grammar, No.12. Tokyo: Kaitakusha.

Allen, M. (1978). Morphological investigation. (Doctoral dissertation, University of Connecticut).

Bauer, L. (1983). English word formation. Cambridge: Cambridge University Press.

British National Corpus (BNC)

Bybee, J. L. (1985). Morphology. Amsterdam: John Benjamins.

Corpus of Contemporary American English. (COCA). Retrieved from http://corpus.byu.edu/coca/.

Cowie, A. P. (1998). Phraseology: Theory, analysis, and applications. Oxford: Clarendon Press.

Cowie, A. P. (1999). English dictionary for foreign learners: A history. Oxford: Clarendon Press.

Database of Analysed Texts of English (DANTE). Retrieved from http://www.webdante.com/index.html.

Hoffman, S. (2001). In (hot) pursuit of data: Complex prepositions in late modern English. In P, Collins, \& A, Smith (Eds.), New frontiers of corpus research (pp. 127-146). Amsterdam: Rodopi.

Hoffman, S. (2004). Are low-frequency complex prepositions grammaticalized? On the limits of corpus data-and the importance of intuition. In H. Lindquist, \& C. Mair. (Eds.), Corpus approaches to grammaticalization in English (pp. 171-200). Amsterdam: John Benjamins Publishing Company.

Hoffman, S. (2005). Grammaticalization and English complex prepositions: A corpus-based study. London: Routledge.

Howarth, P. A. (1998). The phraseology of learners' academic writing. In A. P. Cowie (Ed.), Phraseology: Theory, analysis, and applications (pp. 161-186). Oxford: Clarendon Press.

Huddleston, R., \& Pullum, G. K. (2002). The Cambridge grammar of the English language. Cambridge: Cambridge University Press.

Inoue, A. (2007). Present-day spoken English: A phraseological approach. Tokyo: Kaitakusha.

Inoue, A. (2009). A problem of phonetic notation-stress patterns of set phrases including "day" in dictionaries. English Phonetics, 13, 125-134.

Ishibashi, K. (1966). A dictionary of current English usage. Tokyo: Taisyukansyoten.

Ito, T., \& Sugioka, Y. (2002). Go no shikumi to go keisei (Word mechanisms and word formation). Tokyo: 
Kenkyusha.

Larry King Live Corpus

Michael, M. (2008). Longman Dictionary of Contemporary English, 5th edition. 2008. London: Longman.

Leech, G., Hundt, M., Mair, C., \& Smith., N. (2009). Change in contemporary English: A grammatical study. Cambridge: Cambridge University Press.

Lieber, R. (1983). Argument linking and compounds in English. Linguistic Inquiry, pp. 251-286.

Longman: Longman English-Japanese Dictionary. 2007. Tokyo: Kirihara Shoten.

Mair, C., \& Leech, G. (2006). Current change in English syntax. In B. Aarts, \& A. McMahon (Eds.), The Handbook of English linguistics (pp. 318-342). USA: Blackwell Publishing Ltd.

Makkai, A. (1975). A dictionary of American English idioms. New York: Barron's.

Michael, R. (2007). Macmillan English Dictionary. 2nd edition [MED]. Oxford: Macmillan Education.

Nishikawa, M. (2013). Eigo Setsuji no Miryoku-Goiryoku wo Takameru Tango no Mechanism (Attractive affixes in English: A word mechanism to enhance wordhood). Tokyo: Kaitakusha.

Joanna, T., Diana, L., Dilys, P., Patrick, P., \& Francis, B. (2011) Oxford Advanced Learner's Dictionary. 8th edition [OALD]. Oxford: Oxford University Press.

OED: Oxford English Dictionary (2nd edition) (2009). CD-ROM version 4.0. Oxford: Oxford University Press.

Quirk, R., Greenbaum, S., Leech, G., \& Svartvik, J. (1985). A Comprehensive Grammar of the English language. London: Longman.

Quirk, R. \& Mulholland, J. (1968). Complex prepositions and related sequences. In R, Quirk (Ed.), Essays on the English language: Medieval and modern (pp. 148-160). London: Longman.

Pinker, S. (1994). The language instinct: How the mind creates language. New York, NY: William Morrow.

Plag, I. (2003). Word-formation in English. Cambridge: Cambridge University Press.

Sampson, G. R. (2001). Empirical linguistics. London: Continuum.

Shorter Oxford English Dictionary CD-ROM version 3.0 (6th edition) (2007). Oxford: Oxford University Press.

Siegel, D. (1974). Topics in English morphology. New York, NY: Garland.

Tottie, G., \& Hoffman, S. (2001). Based on: From dangling participle to complex prepositions. In K. Aijimer. (ed.), A Wealth of English (pp. 1-12). Gothenburg: Gothenburg University.

Widdowson, H. G. (1989). Knowledge of language and ability for use. Applied Linguistics, 10(2), 28-137.

Willis, D. (2003). Rules, patterns and words: Grammar and lexis in English language teaching. Cambridge: Cambridge University Press.

Youth Progressive English-Japanese Dictionary (2004). Tokyo: Syougakukan.

\section{Notes}

Note 1. Among the tendencies they noted were (a) a tendency to regularize irregular morphology (e.g., dreamed redreamt) and the elimination of shall as a first-person future marker. (b) revival of the "mandative" subjunctive, probably inspired by formal US usage (we demand that she take part in the meeting)

(c) elimination of shall as a future marker in the first person

(d) development of new, auxiliary-like uses of certain lexical verbs (e.g., get, want-cf.. e.g., The way you look, you wanna/want to see a doctor soon)

(e) extension of the progressive to new constructions, (e.g., modal, present perfect, and past perfect passive progressive (the road would not be being built/ has not been being built/ had not been being built before the general elections)

(f) increase in the number and types of multi-word verbs (phrasal verbs, have/ take/ give a ride, etc.)

(g) placement of frequency adverbs before auxiliary verbs (even in no emphasis is intended-I never have said no)

(h) do-support for have (have you any money? and no, I haven't any money do you have/ have you got any money? 
and no, I don't have any money/ haven't got any money)

(i) demise of the inflected form whom

(j) increasing use of less instead of fewer with countable nouns (e.g., less people)

(k) spread of the s-genitive to non-human nouns (the book's cover)

(l) omission of the definite article in certain environments (e.g., renowned Nobel laureate Derek Walcott)

(m) "singular" they (everybody came in their car)

(n) like, same as, and immediately used as conjunctions

(o) a tendency towards analytical comparatives and superlatives (politer olmore polite)

Note 2. Collocations are defined as "word-combinations that have predictability and collocational range such as deciduous tree, rancid butter" (Inoue, 2007: 105).

Note 3. Many scholars define idioms in terms of semantic non-transparency or non-compositionality; the overall meanings of an idiom (such as spill the beans) cannot be derived from the meanings of each component.

Note 4. Multi-word expressions are defined as phrases consisting of at least two words such as you know what, here we go, here we go again, etc. Unlike idioms, the overall meanings of multi-word expressions are compositional, but change with the contexts in which they are used. For example, Inoue (2007) noted that you know what has varied meanings depending on context.

Note 5. Formulae are fixed expressions such as how are you? Some of these, such as now you're talking and it isn't over until the fat lady sings, are not completely transparent semantically.

Note 6. Larry King Live Corpus is a spoken corpus downloaded from the transcripts of the "Larry King Live" and "Larry King Weekend" on CNN since 1994. The number of words it includes as of March in 2014 is over $30,000,000$. The content and significance of the corpus is fully explained in Inoue (2007: 114ff).

Note 7. Praat is downloadable from http://www.fon.hum.uva.nl/praat/

\section{Copyrights}

Copyright for this article is retained by the author(s), with first publication rights granted to the journal.

This is an open-access article distributed under the terms and conditions of the Creative Commons Attribution license (http://creativecommons.org/licenses/by/3.0/). 